\title{
French Amyloidosis CAPS study: AA Amyloidosis complicating cryopyrin-associated periodic syndrome: a study on 14 cases and review of 53 cases from literature
}

\author{
S Georgin-Lavialle ${ }^{1 *}$, K Stankovic Stojanovic ${ }^{1}$, D Buob ${ }^{1}$, P Quartier ${ }^{2}$, B Neven ${ }^{2}$, I Kone-Paut ${ }^{3}$, E Hachulla ${ }^{4}$, A Belot ${ }^{5}$, \\ L Cuisset ${ }^{6}$, S Anselm7, G Grateau ${ }^{1}$
}

From 8th International Congress of Familial Mediterranean Fever and Systemic Autoinflammatory Diseases Dresden, Germany. 30 September - 3 October 2015

\section{Background}

The cryopyrin-associated periodic syndrome (CAPS) is a rare but treatable inherited autoinflammatory condition including familial cold autoinflammatory syndrome (FCAS), Muckle-Wells syndrome (MWS) and chronic infantile neurologic cutaneous articular syndrome (CINCA). Without treatment, some patients develop AA amyloidosis with consequent renal failure and death.

\section{Objective}

To describe the main features of CAPS-associated AA amyloidosis and the efficacy of interleukin-1 inhibitors in this complication.

\section{Methods}

We retrospectively analysed all current French CAPSassociated amyloidosis cases through the French network for rare diseases, and performed a systematic literature review of such cases published since 1950.

\section{Results}

Fourteen French patients were identified (6 women/8 men) including MWS ( $n=9)$, FCAS $(n=3)$, CINCA $(n=2)$ and having received interleukin- 1 inhibitors in 7 cases. Mean age at the diagnosis of amyloidosis was 22.6 years and five $(35.7 \%)$ patients died. We found 53 patients in the literature, with a sex ratio of 1 . They included MWS $(n=34)$, FCAS/MWS $(n=12)$ and FCAS $(n=7)$. Among 67 patients (French and literature), the median age at amyloidosis

1AP-HP Tenon hospital, Internal Medicin, Paris, France

Full list of author information is available at the end of the article diagnosis was 30 years, ranging from 12 to 61 years. The NLRP3 gene was sequenced in 30 patients (45.5\%), and the distribution of amino acids changes was as follows: R262W $(\mathrm{n}=16)$, T348M $(\mathrm{n}=5)$, A439V $(\mathrm{n}=4)$, D303N $(\mathrm{n}=3), T 436 \mathrm{~N}$ $(n=2)$ and L353P $(n=1) .23$ patients had died (35\%), but none of them had received interleukin-1 inhibitors. Since 2002, 24/67 (36\%) patients with CAPS-associated amyloidosis have received interleukin-1 inhibitors, with at least a decrease of proteinuria and creatininemia in 9 of them (37.5\%)

\section{Discussion}

AA amyloidosis can occur in all CAPS phenotypes, even if it was more frequent in MWS. This study underlines that even if FCAS is considered as a milder clinical phenotype compared to MWS or CINCA, it can also lead to amyloidosis. Thus, if FCAS patients display continuous subclinical inflammation, they should receive Interleukin-1 inhibitors as well, in order to prevent AA amyloidosis. Interleukin-1 inhibitors were introduced since a few years (anakinra and canakinumab), and it is still unclear if they can cure secondary amyloidosis. However, in $39 \%$ of cases they could allow a decrease of both proteinuria and creatininemia. In addition, in our experience and in the literature, anti IL1 treatments were able to prevent amyloidosis-related fatality.

\section{Conclusion}

AA amyloidosis can occur in all types of CAPS. IL-1 inhibitors prevent the occurrence of AA amyloidosis and should be started as soon as possible, even in FCAS patients in case of subclinical inflammation. 


\section{Authors' details}

${ }^{1}$ AP-HP Tenon hospital, Internal Medicin, Paris, France. ${ }^{2}$ AP-HP- Necker hospital, pediatric rheumatology, Paris, France. ${ }^{3} \mathrm{AP}-\mathrm{HP}$ Kremlin-Bicêtre hospital, pediatric rheumatology, Kremlin-Bicêtre, France. ${ }^{4} \mathrm{CH}$ Lyon Sud, Rheumatologic pediatry, Lyon, France. ${ }^{5} \mathrm{CHU}$ Lille, Internal Medicin, Lille, France. ${ }^{6}$ AP-HP Cochin hospital, Genetics, Paris, France. ${ }^{7}$ AP-HP Trousseau hospital, Genetics, Paris, France.

Published: 28 September 2015

doi:10.1186/1546-0096-13-S1-P32

Cite this article as: Georgin-Lavialle et al:: French Amyloidosis CAPS study: AA Amyloidosis complicating cryopyrin-associated periodic syndrome: a study on 14 cases and review of 53 cases from literature. Pediatric Rheumatology 2015 13(Suppl 1):P32.

\section{Submit your next manuscript to BioMed Central} and take full advantage of:

- Convenient online submission

- Thorough peer review

- No space constraints or color figure charges

- Immediate publication on acceptance

- Inclusion in PubMed, CAS, Scopus and Google Scholar

- Research which is freely available for redistribution

Submit your manuscript at www.biomedcentral.com/submit 